\title{
A RELAÇÃO MÃE E FILHO NA PERSPECTIVA PSICANALITICA
}

DOI: $10.22289 / 2446-922 X . V 2 S 1 A 6$

\author{
Constance Resende Bonvicini ${ }^{1}$ \\ Franciely Renata Damasceno Braga ${ }^{2}$
}

\section{INTRODUÇÃO}

Na história da humanidade, o papel da mulher em relação a sua maternagem sofreu várias transformações de acordo com as necessidades de adaptações e interesses sociais vigentes em cada época. Mas foi principalmente no século XIX, que a maternidade ganhou novos desenhos ${ }^{(1)}$. Diante desta perspectiva a modernização dos meios possibilitou a mulher ocupar papéis de suma importância, adquirindo assim autonomia para fazer suas escolhas, entre elas, a maternidade. Nesta perspectiva o objetivo do estudo foi identificar o desenvolvimento do vínculo entre mãe filho na evolução da humanidade.

\section{MÉTODOS}

Este estudo foi realizado, por meio de pesquisas bibliográficas. Foram utilizadas como fontes e materiais de pesquisa: livros da biblioteca da Instituição e de terceiros, artigos, teses e dissertações encontrados em busca de bases de dados do SCIELO. O idioma utilizado é o português, com publicações de 2000 a 2015 e obras clássicas em psicanálise.

\section{RESULTADOS E DISCUSSÃO}

De acordo com o estudo, evidencia-se que no século XIX a mulher passa a assumir além da função nutrícia, a de educadora e de professora, porém à medida que as responsabilidades aumentaram, cresceu também a valorização do devotamento e do sacrifício feminino em prol dos filhos e da família ${ }^{(2)}$. A gravidez é apontada como um período de expectativas e ensaios para o que está por vir, quando os sentimentos e expectativas sobre

\footnotetext{
${ }^{1}$ Mestre em Administração pela faculdade Novos Horizontes. Docente do Departamento de Graduação em Psicologia da Faculdade Patos de Minas (FPM). Rua Major Gote, 1901. Contato: (34)3818-2300. E-mail de contato: constancebonviciniyahoo.com.br

${ }^{2}$ Graduanda em Psicologia pela Faculdade Patos de Minas (FPM).
} 

a maternidade, paternidade, o bebê e seu futuro aflora no psiquismo, formando a ideia do ser mãe e a construção mental da imagem do bebê $\hat{(}^{(3,4,5)}$.

Desta forma, após o nascimento da criança, a quebra da idealização do bebê, a frustração das expectativas criadas quanto à concepção, a não aceitação da criança que nasce diferente do idealizado, provocam desapontamentos. Tais sentimentos e emoções acompanhadas pelo desapontamento da mãe culminam em pensamentos quanto a capacidade de lidar e cuidar do bebê. A mãe pode vir a desenvolver a sensação de impotência, bem como a frustração perante o conflito entre o imaginário e o real, gerando sintomas da depressão pós-parto, destacando-se como característica primordial a não aceitação do recém-nascido, rejeitando-o, até mesmo sentindo-se ameaçada pelo mesmo ${ }^{(6)}$.

\section{CONSIDERAÇÕES}

O estudo aponta para a necessidade de um acompanhamento psicológico da gestante desde o momento da descoberta da gravidez até o fim do período puerperal. Com o intuito de evidenciar fatores que ao longo do desenvolvimento do bebê possam vir a causar frustrações e consequentemente transtornos de depressão pós-parto.

\section{REFERÊNCIAS}

1. Barbosa IBS. A relação mãe-bebê e as possíveis interferências no processo de alimentação. Acta científica. 2012; 4(4):72-73.

2. Moura SMSR, Araújo MF. A Maternidade na História e a História dos Cuidados Maternos. Psic ciência e profissão. 2014; 24(1):44-55.

3. Badinter E. Um amor conquistado: O mito do amor materno. Rio de Janeiro, Brasil: Editora Nova Fronteira; 1985.

4. Bernardino LMF, Laznik MC, Araújo GX. As vicissitudes do encontro mãe/bebê: Um caso de depressão. Est de psicanálise. 2011; (35):49-53. 

5. Schwengber DDS, Piccinini CA. O impacto da depressão pós-parto para a interação mãebebê. Est de psicanálise. 2003; 8(3):403-411.

6. Greinert BRM, Milani RG. Depressão pós-parto: uma compreensão psicossocial. Psic. teoria e prática. $2015 ; 7(1): 32$. 